\title{
First record of Tamarixia radiata (Waterston) (Hymenoptera: Eulophidae) in Misiones province, Argentina
}

\author{
M. E. Schapovaloff $a, b *$ (D), K. M. Bustamante ${ }^{a}$ (D), A. Badaracco ${ }^{a, b}$ (D) and J. P. Agostini ${ }^{a}$ (1) \\ aEstación Experimental Agropecuaria Montecarlo - INTA, Av. El Libertador 2472, CP 3384, \\ Montecarlo, Misiones, Argentina \\ ${ }^{\text {b}}$ Consejo Nacional de Investigaciones Científicas y Técnicas - CONICET, Godoy Cruz 2290, C1425FQB, \\ Ciudad Autónoma de Buenos Aires, Argentina \\ *e-mail: schapovaloff.maria@inta.gob.ar
}

Received: 21 June 2018 -Accepted: 24 September 2018 - Distributed: February 28, 2020

Citrus greening or Huanglongbing (HLB) is considered the world's most destructive citrus disease (Bové, 2006). In Argentina, HLB was detected for the first time in Misiones in 2012 in a tangerine tree (Agostini et al., 2015). HLB is associated with an unculturable $\alpha$-proteobacterium, 'Candidatus Liberibacter' and is transmitted by two psyllid vectors, Diaphorina citri Kuwayama (Hemiptera: Liviidae) and Trioza erytreae (Del Guercio) (Hemiptera: Triozidae). D. citri was reported to appear for the first time in Northwestern Argentina (Augier et al., 2006).

To date, chemical control has been the basis of $D$. citri management programs, but this strategy strongly relies upon frequent applications of a few chemical insecticides throughout the crop season (Yamamoto et al., 2009). Because of this intensive use of pesticides, new control strategies for the vector are being sought, such as biological control. Biological control of $D$. citri can be accomplished using the parasitoid Tamarixia radiata Waterston, 1922 (Hymenoptera: Eulophidae), which is the most effective natural enemy. The idiobiont ectoparasitoid $T$. radiata is native to northern India, where it develops on $D$. citri nymphs, preferentially those in the $3^{\text {rd }}$ to $5^{\text {th }}$ instars (Etienne et al., 2001), and is considered a specialist parasitoid (Zuparko et al., 2011). The female $T$. radiata also kills its host by feeding, and one female can cause the death of up to 500 nymphs from feeding and parasitism (Hoy and Nguyen, 2001).

Considering the importance of citrus crops in Argentina and the biological control of $D$. citri as an alternative management, the present note reports for the first time the presence of $T$. radiata in the province of Misiones.

The search of $D$. citri and its biological controller T. radiata was carried out in Misiones between September 2016 and December 2017. Field collections were conducted in orchards planted with Citrus spp. from different locations and trees of orange jessamine, Murraya paniculata (L.) Jack (Rutaceae) in urban areas. In nine orchards planted with Citrus spp. (less than 4 ha. each) were installed yellow sticky traps $(12.5 \times 10 \mathrm{~cm})$. One trap at each cardinal point and one in the center of the grove were placed, as suggested by Robles García (2012). Also, yellow sticky traps were located in $M$. paniculata distributed in urban areas. The traps suspend from $1.5 \mathrm{~m}$ above the ground were deployed and retrieved from the same trees every two weeks. Traps were transported to the laboratory for further observation under a stereoscopic microscope Leica ${ }^{\circledR}$ with 10 to 40X magnification. For the collection of parasitoids, samples of about $10 \mathrm{~cm}$ long of M. paniculata infested with different development stages (eggs, nymphs and adults) of $D$. citri were collected. Then, in laboratory the young branches with the nymphs of $D$. citri, were incubated at room temperature in plastic Petri dishes, and observed daily for two weeks, for the emergence of parasitoids, which were collected and conserved in ethanol $70 \%$.

With the sampling techniques used in this study, the parasitoid T. radiata was found and registered in yellow sticky traps at citrus groves and $M$. paniculata trees from urban areas, and in nymphs of $D$. citri captured from $M$. paniculata. The adult parasitoids were identified using the characteristics given by Graham (1987) and Ebratt et al. (2011), being in the study period $60 \%$ of females and $40 \%$ of males. The aim of any process of mass reproduction of parasitoids is to obtain the largest proportion of females, since these are the ones that will look for and parasitize the target pest (Valdez et al., 2013). The parasitoid have been found in the species of Citrus tangerines or in its hybrids: Tangor (Citrus reticulata x Citrus sinensis) "Murcott", "Ellendale", "Ortanique", "Nadorcott", Satsuma (Citrus unshiu Marc) "Okitsu"; in sweet oranges: (Citrus sinensis L. Osbeck) "Valencia", "Folha Murcha"; in lemons: (Citrus limon L. Burm.) "Eureka"; in acid lime of large fruit (Citrus latifolia Tanaka) "Tahiti"; in grapefruits: (Citrus paradise Macf.) "Flame", Citrus sp. (Citrus medica L. var sarcodactylis) "Parana"; in plants of orange jessamine $M$. paniculata.

The parasitoid $T$. radiata has been successfully used in various parts of the world to control D. citri and hence HLB (Etienne et al., 2001; Parra et al., 2016). It is important to remark that, for the citrus growers from the different regions it is essential to know, not only the pest D. citri presence, but also the presence of its natural enemy T. radiata, considering that this insect is present in the provinces of Corrientes, Jujuy, Salta, Tucumán, Catamarca and Entre Ríos from Argentina (Cáceres and Aguirre, 2005; Vaccaro and Bouvet, 2005; Lizondo et al., 2007); each of these provinces presents different climatic characteristics to Misiones. High populations of T. radiata in Misiones 
could be the responsible for the low population of $D$. citri found in the citrus groves from this province.

It is necessary to reduce $D$. citri populations to prevent the spread of HLB disease. The report of T. radiata in the province of Misiones encourages the execution of future research that allows mass production and thus consider the release of the parasitoid in the field, together with other biological control alternatives under an integrated pest management program.

\section{References}

AGOSTINI, J.P., PREUSSLER, C., OUTI, Y., 2015. Huanglongbing (HLB) ex greening. In: M.N. ROSSINI, D.M. DUMMEL and J.P. AGOSTINI, eds. Plagas cuarentenarias de frutales de la República Argentina Avances en los resultados. Argentina: INTA, Cap. 6, pp. 183-198.

AUGIER, L.; GASTAMINZA, G., LIZONDO, M., ARGAÑARAZ, M. and WILLINK, E., 2006. Presencia de Diaphorina citri (Hemiptera: Psyllidae) en el Noroeste Argentino (NOA). Revista de la Sociedad Entomológica Argentina, vol. 65, no. 3-4, pp. 67-68.

BOVÉ, J.M., 2006. Huanglongbing: a destructive, newly-emerging, century-old disease of citrus. Journal of Plant Pathology, vol. 88 , no. 7 , pp. 37.

CÁCERES, S. and AGUIRRE, M.R.A., 2005. Presencia de Tamarixia radiata (Hymenoptera: Eulophidae), parasitoide del psílido asiático Diaphorina citri (Hemiptera: Psyllidae) en cultivos cítricos de Corrientes. Revista de la Sociedad Entomológica Argentina, vol. 64, no. 4, pp. 348-349.

EBRATT, E.E., RUBIO, L.T., COSTA, V.A., ZAMBRANO, E.N., CASTRO, A.P. and SANTAMARIA, M.Y., 2011. Primer Registro de Tamarixia radiata (Waterston, 1922) (Hymenoptera: Eulophidae) en Colombia. Revista Facultad Nacional de Agronomía, Medellín, vol. 64, pp. 6141-6146.

ÉTIENNE, J., QUILICI, S., MARIVAL, D. and FRANCK, A., 2001. Biological control of Diaphorina citri (Hemiptera: Psyllidae) in Guadeloupe by imported Tamarixia radiata (Hymenoptera: Eulophidae). Fruits, vol. 56, no. 5, pp. 307-315. http://dx.doi. org/10.1051/fruits:2001131.
GRAHAM, M.W.R.V., 1987. A reclassification of the European Tetrastichinae (Hymenoptera: Eulophidae), with a revision of certain genera. Bulletin of the British Museum (Natural History), vol. 55 , pp. 1-392.

HOY, M.A. and NGUYEN, R., 2001. Classical biological control of Asian citrus psylla. Citrus Industry, vol. 81, pp. 48-50.

LIZONDO, M.J., GASTAMINZA, G., COSTA, V.A., AUGIER, L., GOMEZ, M.L., WILLINK, E. and PARRA, J.R., 2007. Records of Tamarixia radiata (Hymenoptera: Eulophidae) in northwestern Argentina. Revista Industrial y Agrícola de Tucumán, vol. 84 , pp. 21-22.

PARRA, J.R., ALVES, G., DINIZ, A.J. and VIEIRA, J., 2016. Tamarixia radiata (Hymenoptera: Eulophidae) x Diaphorina citri (Hemiptera: Liviidae): mass rearing and potential use of the parasitoid in Brazil. Journal of Integrated Pest Management, vol. 7, no. 1, pp. 1-11. http://dx.doi.org/10.1093/jipm/pmw003.

ROBLES GARCÍA, P.L. 2012. Protocolo para establecer áreas regionales de control del Huanglongbing y el psílido asiático de los citricos (ARCOs). México: Dirección de Protección Fitosanitaria, pp. 1-60.

VACCARO, N.C. and BOUVET, J.P. 2005. Registro de un Enemigo Natural de la Chicharrita de los Cítricos en Entre Ríos. In: Anales del V Congreso Argentino de Citricultura, 2005, Concordia, Entre Ríos, Argentina. Tucumán: Universidad Nacional de Tucumán, pp. 73.

VALDEZ, N.I., GÓNZALEZ, J.A., HERNÁNDEZ, A. and BERNAL, H.C., 2013. Parámetros biológicos en el control de la calidad en la producción masiva del parasitoide Tamarixia radiata (Waterston) (Hymenoptera: Eulophidae). Vedalia, vol. 14, no. 1, pp. 31-34.

YAMAMOTO, P.T., FELLIPE, M.R., SANCHES, A.L., COELHO, J.H.C., GARBIM, L.F. and XIMENES, N.L., 2009. Eficácia de inseticidas para o manejo de Diaphorina citri Kuwayama (Hemiptera: Psyllidae) em citros. BioAssay, vol. 4, no. 0, pp. 1-9. http://dx.doi.org/10.14295/BA.v4.0.21

ZUPARKO, R.L., DE QUEIROZ, D.L. and LA SALLE, J., 2011. Two new species of Tamarixia (Hymenoptera: Eulophidae) from Chile and Australia, established as biological control agents of invasive psyllids (Hemiptera: Calophyidae, Triozidae) in California. Zootaxa, vol. 2921, no. 1, pp. 13-27. http://dx.doi. org/10.11646/zootaxa.2921.1.2 